\title{
The Social Embeddedness of the Dance Culture in a Moldavian Village
}

\author{
Vivien Szőnyi \\ Hungarian Academy of Sciences, Budapest \\ Institute for Musicology, Research Centre for the Humanities
}

Received 15 July 2018 • Revised 27 August 2018 • Accepted 20 September 2018

\begin{abstract}
The present research examines those changes that happened between the 1940s and the $2010 \mathrm{~s}$ to the dance culture of a Moldavian Csángó village of East Romania called Magyarfalu. In the light of a holistic approach and on the basis of archive data and fieldwork, the leading aims are to identify those adaptation practices that lie behind the transformation of the dance culture, the triggers thereof, that is the micro or macro processes which induced the adaptation in the local community and to find an answer to the following question: what is the function that dancing itself fulfils in the life of the village when the phenomenon is regarded as social practice. The results suggest that the changes in the dance culture are triggered by ecological, economic, social, and cultural mechanisms; through the adaptation practices, the dance culture's self-organised and institutional forms allow the members of the community to attain cultural, social, and economic capital, in addition to that, satisfying certain needs and requirements of the community, contribute to the harmonious functioning of the social structure of Magyarfalu. In the present paper, the social embeddedness is demonstrated by real cases and it is proven that the theoretical frameworks of biopsychology and structural-functionalism are relevant when the anthropological eye turns upon the dance research.
\end{abstract}

Keywords: Moldavia, Csángó, dance anthropology, functionalism, adaptation.

\section{Introduction}

The present essay focuses on the social embeddedness of dance culture in solely one Moldavian Csángó village called Magyarfalu (Arini) ${ }^{1}$, that is, examines the role thereof played in the social structure by carrying out the analysis of several adaptation practices. The transformation that has taken place in the dance life of the micro community since the 1940s until these days are interpreted in the context of ecological, political, economic, and social mechanisms. Alongside the aim to highlight the dynamic connection between the dance culture and the society, the present paper sets a purpose to prove that the theoretical and methodological framework of functionalism, applied in social anthropology, is also relevant when it comes to dance anthropological research.

${ }^{1}$ Magyarfalu (Arini in Romanian) is of Hungarian ethnic origin and situated in Bacău County in Northeast Romania as part of the municipality of Găiceana.

(c) Authors. Terms and conditions of Creative Commons Attribution 4.0 International (CC BY 4.0) apply. Correspondence: Vivien Szőnyi, Institute for Musicology, Research Centre for the Humanities, Hungarian Academy of Sciences, 7 Táncsics Mihály Street, 1014 Budapest, HUNGARY. E-mail: szonyivivien@gmail.com. 
The research objective and the subject are considered to be relevant due to the following two aspects. Despite the fact that the Hungarian ethnological research turned its attention mainly to the Moldavian Csángó ethnic group (Ilyés, Pozsony \& Tánczos, 2006), profound research has not been conducted on the community's dances and dance life. A holistic research of functionalist approach carried out on a dance culture which is embedded in the community's social life may bring to light mechanisms that challenge the already existing theories and provides a different perspective upon the role and the importance of dance, in addition to that, an evidence shall be emerge on the complexity of culture and the importance of adaptation practices that are required to maintain the social functioning.

- The transformation of the dance culture in Magyarfalu has been triggered by collective, cultural, social and ecological practices.

- Micro, meso, and macro level mechanisms led the community to apply adaptation practices.

- Satisfying individualistic and common needs, the dance culture helps to sustain the continuity of the social structure.

Furthermore, it has to be highlighted that meanwhile the Hungarian folk dance and music research gained international reputation and attained outstanding achievements ${ }^{2}$, the positivist, comparative, and formal approach of historical perspective, sometimes supplemented by a quaint or ethnocentric point of view, have still not been detached completely from the research methodology after the mid-20 $0^{\text {th }}$ century. The recent generation of researchers participating in the Hungarian folk dance research study groups ${ }^{3}-$ of which the author of this essay is a member as well - are guided by the aim to reconsider the outcomes achieved so far and develop a critical approach thereto, place the dance culture in an interdisciplinary perspective, follow the contemporary theories and methods of human and social studies (see Fügedi, 2018a, 2018b; Kavecsánszki, 2015; Pál-Kovács, 2014; Székely, 2017; Szőnyi, 2014a, 2016; Varga, 2017), moreover, the objective of publishing their results on international level is also a matter of priority.

\section{Research Hypothesis and Questions}

The research hypothesis of utmost importance indicates that dance has a function and this triggers the manifestation of such an institutional system in the community's social structure which is peculiar to the dance culture itself. Starting from the functionalist approach and the concept of cultural complexity, the example of Magyarfalu suggests that the changes happened to traditional dances 4 in terms of formal, functional, stylistic, and social aspects and the transformation of dance life 5 , which provides the framework of learning, performing and using the

${ }^{2}$ As far as folk music research is concerned, see the work and publications of Béla Bartók and Zoltán Kodály; when it comes to folk dance research, György Martin's work is to be referred.

3 Archives and Department for Folk Music and Folk Dance Research, which belongs to the following institute: Hungarian Academy of Sciences - Research Centre for the Humanities - Institute for Musicology; Department of Ethnology and Cultural Anthropology at the University of Szeged; Hungarian Association for Ethnochoreology.

4 This essay pays attention solely to the traditional or so called folk dances which persist in the informant's memories or have been survived until today in the peasant dance culture or to those dances that have been 'revised' or taught back to the members of the community. A wide range of these dances appears in the repertoire of the village's dance assembly when they dance on the occasion of a stage performance, dance event, or ethnological fieldwork. In addition, most of those dances that are performed on dance events attended by the whole village or on family occasions are also regarded as folk dances.

5 The term 'dance life' refers to the socio-cultural frame of a dance and consists of the following key elements: the dance events, the customs connected to dancing, the organisation of the event, the dance etiquette, the institutional structure of dance acquisition and music arrangement (Felföldi, 1996: 106-107). 
village's set of dances, are the consequences of the common and individual adaptation practices. Interrelating ecological, political, economic and sociocultural processes, such as the climate change, the changing of the political regime, labour migration or the assimilation of diverse ethnic groups and languages lie behind the adaptation itself. The present essay outlines what progress has been made in this research so far, however, the results are not regarded as final conclusions. For this reason, taking the research hypothesis as the point of departure, this paper is aimed at finding answers to the following questions:

(a) How to apply the theoretical and methodological results gained by the functionalist branch of British social anthropology when the research turns to the dance culture?

(b) What are those adaptation practise that lie behind the changes happing to the dance culture of Magyarfalu?

(c) Which mechanisms led the community to go through the process of adaptation?

(d) What are those manners by which the dance culture contributes to the continuity of the social structure?

\section{Research methodology}

\subsection{The field}

The site of the fieldwork, Moldavia, belongs to Romania today and lies between the East Carpathian Block and the Prut River, the borders thereof are Bukovina on north, the Lower Danube and the Black Sea on south. The majority of those settlements which are populated by the so called moldvai csángó (Moldavian Csángó) ethnic group of Hungarian origin is situated along the river Szeret in Bacău County (Pozsony, 2005: 7-8). Among the Csángó group, relocated from Transylvania in the $12-13^{\text {th }}$ century and from Székelyföld in the $18^{\text {th }}$ century to Moldavia, approximately 40, ooo people still speak Hungarian ${ }^{6}$. The Moldavian Csángó identity is primarily based on two aspects: the Roman Catholic religion which separates the Csángó group from the Romanians of Orthodox religion living around them, and the local identity.

\subsection{Magyarfalu, the village concerned in the research}

Magyarfalu is located $60 \mathrm{~km}$ from the centre of Bacău County and belongs to the Găiceana community as the only settlement of Roman Catholic religion. As far as the Hungarian language concerns, the situation is favourable despite the fact that the language of instruction is Romanian at the local nursery and school.7 At the beginning of the 2000s, a Hungarian school has been established by the Moldvai Csángómagyar Oktatási Program (Moldavian CsángóHungarian Education Programme) which institute offers facultative after-school programmes for children.

The village counts 1300 inhabitants, however, due to the large-scale labour migration solely 700-800 people live there permanently (Iancu, 2013: 58). The labour migration is considered to be the most important factor for cultural transformation, in particular, the growing incomes resulted in an increasingly modern way of living. The target countries for those who work abroad: Germany, Italy, Israel, the Democratic Republic of the Congo, and the Equatorial Guinea. In the countries mentioned before, the men of Csángó origin work mainly at construction sites.

\footnotetext{
${ }^{6}$ Based on the research conducted by Vilmos Tánczos between 1992 and 1966, around 62, ooo out of the 240, ooo Moldavian people of Catholic religion speak Hungarian. Since then, a significant decrease has been observed in the rate of Hungarian-speaking people (Ilyés, Peti \& Pozsony, 2010: 127).

7 In the 1950s, in some Csángó villages the instruction in Hungarian language used to be an option, likewise in Magyarfalu, however, after a few years this opportunity has no longer been provided.
} 
Those who reside permanently in Magyarfalu are engaged in peasant farming, that is, land cultivation and animal breeding. Magyarfalu is a dead end village with a cohesive community where the way of living corresponds to a regulated system. Both the moral order and the legal system are of ecclesiastical origin and highly dependent on the church's supervision (Iancu, 2013: 60-62).

\subsection{Methodology and the resources for the research}

I have been conducting ethnological research on the Moldavian Csángó ethnic group with the main focus on their social structure and dance culture since $2012^{8}$. My ongoing doctoral research has started to be undertaken in Magyarfalu, in the year of 2015, and since then, I conducted 1-2 weeks long fieldworks in each season with in exception for 2016, when I spent 3 months in the field. As far as the resources concerns, the fieldwork has greater dominance, while the rest of the collected data comes from archives (manuscripts, photos, and film libraries). ${ }^{9}$ The participant observation, ${ }^{10}$ the half-structured interviews, the photo shooting, and the filming of dances have to be mentioned as data collection methods. The dance events taken under observation - e.g. festivals on the occasion of saints' days, weddings, and balls - have been organised by the local community, I participated solely as a guest, a researcher, or a dancer with no coordinating or controlling intervention. A research conducted for an extensive period of time and the complex nature of the questions, resulted in a wide range if interviewees: inhabitants of Magyarfalu, between the age of 18-98; my social network formed in the village allowed me to visit them.

\section{Interpretative framework}

\subsection{Holistic approach}

The discourse of the research is primarily based on the holistic approach, therefore, my aim is to observe a cultural phenomenon in its context not by itself. I share the view that an element isolated from the sociocultural system cannot be explained independently but in relation to the other components (Hollós, 1995: 4-5; Kisdi, 2012: 110). The holistic point of view requires the anthropologist to develop a broad perspective because it takes into consideration further aspects as the visible and non-visible (hidden) dimensions, the changes over time and space, and the conditions of interactions that trigger the transformation of a cultural phenomenon. Assuming a cultural complexity, this concept implies that the transformation of solely one cultural element impacts all the other components of the system (A. Gergely, 2010b: 174; Felföldi, 1996: 100-101). The research methodology is also affected by this approach because the researcher is demanded to conduct a long-term fieldwork in order not to examine the changes happening to a phenomenon solely in a short interval but gain insight also into the dynamics thereof (A. Gergely, 2010b: 175; Felföldi, 1996: 107). Eriksen claims (2008: 6), in order to understand a phenomenon in its complexity, the research is required to start from a multidimensional viewpoint and the focus has

\footnotetext{
8 Since 2012, I have been carried out fieldwork in the following settlements: Bacău County - Lábnyik (Vladnic), Somoska (Somuşca), Klézse (Cleja), Máriafalva (Lărguţa), Csík (Ciucani), Magyarfalu (Arini), Szitás (Nicoreşti), and Újfalu (Satu Nou); Vrancea County - Vizánta (Vizantea-Mănăstirească). In the school year of 2014/2015, I have worked as a Hungarian language teacher in Szitás, for this reason, I had the opportunity to spend an entire year living in a Csángó village community.

9 During the research, the archives of the following institute has been analysed: Archives and Department for Folk Music and Folk Dance Research at the Hungarian Academy of Sciences - Research Centre for the Humanities - Institute for Musicology.

${ }^{10}$ When it comes to dance anthropological research, in methodological regard, a particular importance has to be attached to the researcher's body during in the course of dancing.
} 
to be placed on the interactions between the levels of the system, surpassing the standardised ways of outlining solely the causes and the effects.

At this point, it has to be demonstrated how this approach can be applied in dance research. According to Anca Giurchescu and Lisbet Torp (1991: 7), the holistic perspective in dance research can be developed by combining the disciplines of the American and European dance research, that is, the anthropological and choreological aspects. When it comes to dance research of anthropological approach, the focus is places on the 'dancers', that is, on the community and the socio-culture context thereof, while the European ethnochoreology examines the dances in terms of historical, formal or functional perspectives and aims at classifying and comparing the dances or examining the changes happening to them (Giurchescu \& Torp, 1991: 1-3; Kaeppler, 1991: 11-13). Since the 1970s, it has been required to take the social context into account also in the field of Eastern European dance research (Giurchescu \& Torp, 1991: 5), however, only a few examples proved its practical implementation.

In my opinion, examining the dance culture in a holistic perspective is not restricted to the overall observation of the dances and the dancers' community but implies the application of a multidimensional perspective which takes into account all the possible macro, meso, and micro mechanisms that happen in the transformation of dancing. The research has to be problemcentred, starting from one statement (research problem), the factors of the problem, and the interactions thereof shall be examined from a widening point of view and based on a synchronic approach. This way of thinking might lead to understand the main point of a phenomenon, in this case, the substantiality of dance itself. However, it differs from one anthropological school to another that what they consider to be essentiality. The functionalists, including the author of the present essay, take the view that the form is determined by the function, for this, the substantiality of the examined phenomenon corresponds to its role played in the society, that is, the function represents the essence of an entity (Kisdi, 2012: 106).

\subsection{The Functionalist branch of British social anthropology}

This section shall be devoted to demonstrate the important statements made by the biopsychological stream and the theoretical school of structural functionalism in British social anthropology. In the beginning, these approaches were not able to coexist due to the professional differences between the pioneer theorists, namely Bronisław Malinowski and Alfred Reginald Radcliffe-Brown. On the contrary, I believe that the action-based and the structural approaches of functionalism complement each other as long as the aim is to interpret the different levels of the society from a holistic point of view (Kisdi, 2012: 117).

\subsubsection{Biopsychological functionalism}

The theoretical and methodological principles of the paradigm of biopsychological functionalism have been developed by Bronisław Malinowski. He claims that all cultural phenomena serve to address biological needs of which seven are considered to be fundamental: nutrition, reproduction, bodily comforts, safety, health, movement, and growth. The society gives room for satisfying the needs mentioned before, that is, the collective responses appear in the social context and the occurrence of which brings the social institutions into being. Malinowski regards the culture as an organic whole and in order to understand it, the biological needs, the environmental factors, and the reactions have to be examined altogether (Kisdi, 2012: 105-106).

This functionalist approach bases on the 'active man' and on the biological features thereof (A. Gergely, 2010a: 162). In functionalist dance research which I also represent, this theory might be applicable mainly in the micro level observation of small communities. The micro level 
is meant to be interpreted as the social network of those people who know each other in a direct or indirect way due to the fact that they belong to the same local community. Consequently, the examination of dance culture in a biopsychological and micro level perspective starts with the observation of the individual dancers and aims at finding an answer to the following question: what are those social institutions of the community that have been constructed by dancing interpreted as a collective response to one (or more) need(s). As long as Magyarfalu concerns and on the basis of the experience gained during the observation period (1940s-2010s), the dance life have been organised and controlled by the local community in accordance with the morals and values dominating in the village. I presume that more emphasis has to be placed on this micro level perspective for the purpose of understanding the role of dancing in terms of individual and collective aspects. This attempt per se might lead to misinterpretations so long as other aspects have not been taken into consideration, that is, the observation of those factors which influence the social life and the network of meso level institutions (the town hall, the local church and school) which act as a bridge between micro and macro levels.

\subsubsection{Structural functionalism}

The structural functionalism, developed by Alfred Reginald Radcliffe-Brown, represents the other branch of the British social anthropology and claims that the cultural elements serve to address the preservation of the society, so that, the needs for that purpose should be examined instead of the biological ones (A. Gergely, 2010a: 162; Boglár \& A. Gergely, 2010: 161). Three concepts have been introduced by Radcliffe-Brown's theory. The first one is the social structure, a wide network of social relations, the constituents of which are persons arranged in a regulated relationship (Kisdi, 2012: 115; Radcliffe-Brown, 2004: 18-20). The concept of social structure is followed by the structural continuity standing to prove that the continuity is dynamic despite the changes happing to the elements of the structure (Kisdi, 2012: 115). The function represents the third notion which implies that a certain social practice or attitude plays a role in sustaining the social continuity throughout its function (Kisdi, 2012: 116; Radcliffe-Brown, 2004: 21, 157, 173). Radcliffe-Brown regards the culture as a form of social life and claims that the society's normal state bases on the equilibrium which originates from a regulated relationship existing between the individual and the community (Kisdi, 2012: 116; Radcliffe-Brown, 2004: 14).

The prime factor of this functionalist approach is not the individual but the whole structure, the order of which is interpreted in the context of the structure, the continuity, and the function (A. Gergely, 2010a: 162). For this reason, I suppose this approach helps to understand those macro level processes which contribute to the transformation of dance culture and the role of ecological, political, economic, and social mechanisms played in shaping and constructing the culture. While the action-based functionalism is able to highlight the specific features and characteristics of a community, the structural functionalism provides understanding of how the society works from a general and universal point of view. Relying on Radcliffe-Brown's concept of adaptation, I regard the culture as an adaptive system in the sense of which my aim it to find an answer to the following question: during the transformation of the dances and the dance life of Magyarfalu, what sort of internal adaptive responses (micro level) have been given by the community to certain external mechanisms (macro level) in order to preserve the continuity of the local dance culture (Radcliffe-Brown, 2004: 17-18).

\subsection{The anthropological interpretation of dance culture}

The American dance anthropology realised for the first time that dancing allows the human body to express itself, the social reality in which the community lives, and the changes happening thereto (Kaeppler, 1991: 12; Kürti, 1995: 140-143). Narrowing down the interpretative framework of the research, dancing is regarded as a sociocultural practice. Therefore, the research subject does not refer to dancing as a movement system, rather as a social practice regulated by 
the community. Consequently, more emphasis has been placed on the observation of the customs, in the frame of which the dance events take place, the dancing community, and the social network which sustains the dance culture, while the comparative analysis addressing the form bears less relevance (Felföldi, 1996: 100; Kavecsánszki, 2014: 75-76).

The fact that a sociocultural practice means more than itself and goes beyond the visible and perceptible formal or functions features, has been observed in the past by other researchers besides myself. Sándor Veress, a Hungarian researcher of folk music, added the following note on the Csángó folk singing practice to his field diary, when he carried out a research in Moldavia in 1930:

"This is not time for singing and they adhere to this principle consistently (...). I have had an impression since I came here that singing is somehow not spontaneous, natural, or, if I might say that, a basic need in contrast to the Székely ${ }^{11}$ ethnic group or the Hungarian peasants as I experienced. For these people, singing means working or an activity of uncommon nature, (...)"12.

As long as dancing concerns, the same observation can be made in Magyarfalu where dancing is connected to a specific time and space, additionally, the age and the social status of the participants of the dance occasions are stated as well. From now on, I am aimed at representing the changes that happened to the dance culture of Magyarfalu and the role played by dance life in sustaining the social continuity, in addition to that, I would like exemplify through concrete cases the social embeddedness of dance life.

\section{Adaptation practices in the dance culture}

According to Radcliffe-Brown (2014: 17-18), so long as the culture - also referred to as social living - is examined as an adaptation system, a distinction has to be made between the three aspects of this social arrangement. The cultural adaptation might be mentioned at the first place, by the help of which, a person acquires certain habits and mental abilities in order to be capable of participating in the social action and the social life. Along whit this, the institutional aspect of social adaptation comes to the picture which includes those social arrangements that facilitate the cooperation and the preservation of social continuity. Lastly, the ecological adaptation also has to be taken into account, which implies the adaptation to the physical environment.

\subsection{Cultural adaptation with regard to the dance culture of Magyarfalu}

As the Moldavian folk dances in general, the repertoire of Magyarfalu is featured by circle dances of regulated structure, couple dances and those types that blend circle and couple dances into each other. The range of dances is remarkable as I have managed to register 6o dances so far ${ }^{13}$. The motives of these dances are repetitive (strophic) and their structure is divided into phases. As long as their origins concerns, the following dance cultures had the most remarkable influence on the form of the dances in question: Romanian, Bulgarian, Ukrainian, German, and

\footnotetext{
${ }^{11}$ A Hungarian ethnic group living in the Southeaster part of Transylvania, in Romania.

${ }^{12}$ The note has been taken on the $25^{\text {th }}$ of July in 1930, in the village of Forrófalva (Fărăoani) (Veress, 1989: 309).

13 This does not imply that all those dances are still known and performed in these days.
} 
Polish (Martin, 1996: 127)14. In these days, among the dances of Magyarfalu, the so called csárdás couple dance is detectable, which is accompanied by a traditional-like constructed song having the 'Az a szép, akinek a szeme kék' (The beautiful is the one who has blue eyes) opening line, when it comes to the performance of children's groups in the village. The csárdás dance, evolving in the $19^{\text {th }}$ century, has a symbolic meaning as the national Hungarian couple dance, for this reason, its stage performance might be regarded as the expression of ethnicity. So far as we know, the csárdás appeared in Magyarfalu solely in the recent past, and this is proved by the facts that this dance neither left a mark in the memory of older generations, nor belongs to the repertoire of the current dance events, and turns up only at the performances of the children's groups.

I believe that a cultural adaptation process lies behind the local appearance of the csárdás and this phenomena is related to the Hungarian schools' endeavour. In the 1950s, the language of instruction has been Hungarian for a couple of years in the Moldavian Csángó settlements, consequently in Magyarfalu as well, when the teachers usually taught this folk-style art song to the children. For this reason, this song has been living in the locals' mind as a representative segment of the 'original Hungarian' culture, in addition to that, the melody has included in the regional gypsy bands' music repertoire. From the second half of the 1950 s to the present time, the children has been involved in Romanian education, however, from the 2000s, there has been a possibility to attend a Hungarian school as an extracurricular activity. As part of the project, a local-born woman organised programmes aiming at preserving the Hungarian tradition and she taught folk songs and dances to the children ${ }^{15}$. Based on their age, she divided the kids into two groups and taught them her own csárdás choreography which was accompanied by the 'Az a szép, akinek a szeme kék' melody. This dance is not embraced by the local community, however, when it comes to the children's dance performances, the csárdás is performed as it was belong to the local dances.

I consider two inducing mechanisms to lie beyond this phenomenon, one of them is the so called 'Csángó-saving' movement, and the appearance of rural tourism in Magyarfalu is regarded as the other factor. After the changing of the regime in Romania, the protection of the Moldavian Csángó people's interest, in terms of cultural and social aspects, became popular within the academic and the laic circles as well (Peti, 2006: 129-130; Tánczos, 2003: 67). This point should be set in context, beside political reasons, the Hungarian ethnologists and the member of the táncházmozgalom (dance-house movement) ${ }^{16}$, guided by a 'romantic and idealizing' aim (Hatos, 2002: 5), assumed that the saving of the Csángó culture, considered to be archaic, is their mission (Peti, 2006: 133, 137, 141). The representative function of the folk dance and music culture gained utmost importance in this process, for this reason, folk dance assemblies were established in several Csángó communities and these groups travelled to Hungary for guest appearance or hosted the Hungarian tourists in their own villages. This intervention, aiming at saving this culture, had an impact on the identity, the social life, and the culture of the Moldavian communities, in addition to that, led them to give local responses to these mechanisms (see Szőnyi, 2014b). In my opinion, the above described case of Magyarfalu, represents an individually initiated adaptation practice, that is a local response, which provides the opportunity of

14 The wide range of the dance repertoire might be attributed to the fact that the region in question is a transition area where the communities living together have always been diverse in terms of religion, ethnicity, culture, or cultural background due to the persistent immigration and internal migration.

15 This woman was born in 1949 .

${ }^{16}$ The first dance-house has been organised in 1972 in Budapest. This phenomenon, which means that the dance events of the village communities have been transferred to the urban context, might be regarded as a complex episode of folklorism, revival, and cultural history. Based on the traditional roots, the improvisation part takes place at these events alongside with dance teaching and other programmes. This phenomenon, apart from transmitting aesthetic values, bears the function of community-building and entertaining (Sándor, 2006: 23-34, 38). 
representation, in the frame of which, the community is able to express its identity to a wider ethnic community, additionally, the real or perceived needs of Hungarian tourists shall be satisfied.

\subsection{Social adaptation with regard to the dance culture of Magyarfalu}

The institutional aspect of social adaptation shall be illustrated through a dance event which is connected to the most important turning point in human life. Between the 1950s and the 1970s, the wedding or nunta ${ }^{17}$ (local term) has lasted for 3 days. The first day of the wedding was spent at the bride's house, to where solely those friends and relatives were invited who have not been married yet; on the second day, all the married members of the village community were allowed to celebrate at the bridegroom's residence. The third day was the so called palakányia when the narrower circle of family members and those who took active participation in the preparation process consumed the leftovers and held a private festival. In the 1970s, besides the church wedding, the civil ceremony appeared which has been followed by the so called konónia ${ }^{18}$ festive dance event. This event has taken place 1 or 2 weeks prior to the church wedding and solely the youngsters were allowed to participate. On the occasion of the konónia, musicians were invited, a dinner was offered and the dancing event lasted all evening, in addition to that, the young couple received gifts and presents. For this reason, the three day long wedding shortened to two days as the dance event organised at the bride's residence has been replaced by the konónia. From the 1990s, the konónia, as an independent dance event, has completely vanished from the village's dance life. The civil and the church weddings are organised on the same day, followed by a one night long celebration, and it comes to the palakányia only in exceptional cases.

Beyond the vanishing of the konónia, the local parish-priest's order lies which does not allow for youngsters to celebrate the civil wedding. The priest bases his decision on moral matters as he supposes that the young couples consummate the marriage right after the civil ceremony's night which means that at the church wedding, 1 or 2 weeks after the civil part, they are not pure any more in the presence of God. For this reason, the priest abolished the konónia and requested the major to host the civil ceremony in the village on the same day when the church wedding takes place. This caused some outrage among the youngsters ${ }^{19}$, however, under whole community's pressure, they gave a way to this social requirement and complied with this ethical obligation $^{20}$.

As I indicated above, the Csángó identity is based on the following two main aspects: the local identity and the religion in particular, because their Roman Catholic religion represents the 'essence of the community' (Kinda, 2010: 23). From the 1960s, in the Moldavian Csángó villages the priest has been playing 'the social role of utmost importance in the village's community and corresponding to this, he has been the most influential member' (Kinda, 2010: 116). In Magyarfalu, he guides the sacral and social life of the community, enforces the moral norms and claims the right to intervene in the everyday life of the village and the personnel matters of families

17 In the Moldavian Csángó villages, the Hungarian expression of menyekező or the Romanian nuntă is in use to define the wedding.

${ }^{18}$ This term can be traced back to the Romanian cununie civilă which corresponds to the expression of civil wedding in the Moldavian dialect.

${ }^{19}$ Some members, belonging to the generation of those former days, got married in a few years and the local practice required them to invite each other to celebrate the konónia. After abolishing the konónia, some of them remained in disgrace as they had no chance to invite the others to their own konónia in return.

${ }^{20}$ Written sources remained even from the 1930s, report that in the Moldavian Csángó villages it was forbidden by the priest to dance in a couple with someone from the same gender as they considered this to be immoral (Csüry, 1930: 3). 
or individuals. The standpoint represented by the parish is not only of religious nature but political interests might play a part as well, as the Roman Catholic Church is actively involved in the assimilative endeavours of the Romanian state (Pozsony, 2005: 87, 92). Beyond that, the church refuses the Hungarian language and provides the holy mass in Romanian, tries to hold the Hungarian traditions in their bay, and transform the locals' cultural memory.

When it comes to Magyarfalu, the following case provides a good example for the effective cooperation between the orders issued by the public sector and the executive power of the parish: the date for celebrating the village's saint has been modified due to ideological reasons and as a result, the day of the community's most important dance event has been changed. Magyarfalu's patron saint used to be Saint Stephen (Hungarian king), for this, until the year of 1967, the celebrations have been held on the $2^{\text {nd }}$ of September. Later on, the priest at that time, due to the pressure of national politics, has changed the day of celebration to the $8^{\text {th }}$ of September which is the memorial day of Saint Mary's birthday ${ }^{21}$. All in all, it can be recognised that the parish represents the most influential authority which cannot be separated from the government, additionally, the priest is the leader of both the religious and the moral life so the acceptance of his decisions serves to address the continuity of a harmonious social life.

\subsection{Ecological adaptation with regard to the dance culture of Magyarfalu}

Finally, the culture-shaping effect of the physical environment has to be taken into account. The ecological adaptation is a natural phenomenon taking place in every culture, as this is an essential criterion for any community's survival. The natural environment is placed at a higher level, above the network of political, economic, and social mechanisms, regarded as macrolevel factors in this research, however, significant changes have rarely been triggered by this factor or when they have, the transformation of the community's culture has happened in a slower way. Those shocking natural disasters are exceptions that come about every once in a while and force people to speed up their reactions. The turning point of that sort shall be demonstrated by those radical changes that happened to the dance life of Magyarfalu in the 1940s.

Based on my informants' narratives, there were no radical changes in the practices relative to the dance events, the organisation thereof, and the arrangements with the musicians between the 1940s and the 1960s. Those dance events that involved the whole community and connected to festivities, such as Christmas, New Year, Epiphany, Easter, Pentecost and the patron saint's day, have been organised in the same way as always. The regular dance events took place on every Sunday afternoon, except for the period of fasting, at the village centre. When it comes to the turning points in human life, people were dancing on the occasion of the marriage offers and during the three day long weddings. These occasions were organised by young people living in the village, and they were in charge to take these events under control. Every Christmas, the local lads nominated the so called vatáv $v^{22}$ amongst them who was the main organiser by leading a small group. With his peers, he hired the Gypsy band from the neighbouring village of Băcioiu, and the musicians were hosted (dinner and accommodation has been provided for them) by the so called vatazsica $^{23}$ girls helping for the local parish. Every once in a while, the local musician were hired, however, this happened solely when the community was not able to cover the costs of the gypsy

${ }^{21}$ Despite that fact that the following does not relate tightly to the examination of the dance culture, it should be mentioned that the Romanian name of Magyarfalu has been changed from Ungurii (means Hungarians) to Arini in 1968, because the latter name does not refer to the village's ethnic origin.

${ }^{22}$ The term vatáv, in the Moldavian Csángó dialect, corresponds to the Romanian vătaf which has the following meanings: count, captain, commander, leader, and chief.

23 The term vatazsica, in the Moldavian Csángó dialect, corresponds to the Romanian term of vătăşiţă which has the following meanings: bridesmaid, housekeeper, and wife of the bailiff. 
band. This short description exemplifies that Magyarfalu used to have a dynamic dance life in the period mentioned before, due to the fact that the dance events have been kept under control by the local community. Between 1947 and 1948, a temporary but radical change has happened to the dance culture: those dance events which followed the common practice has been terminated, that is, dancing occasions were not held neither at the weekends, nor during the holy days or after the church weddings.

An environmental disaster lies behind the radical change described above, in 1946-47, a heavy drought desolated the whole region of Moldavia. The abnormally dry weather resulted in famine and the whole phenomenon wore on the community that makes a living from agriculture in the first place 24 . Almost the entire young population migrated to Transylvania and to the Banat where they worked mainly as day-labourers or maids. They managed to get employed primarily in the settlement of Hungarian language, in the middle and the southwestern part of Romania where they learned several Hungarian folk songs or traditional-like constructed songs, and after the drought, they carried these melodies back home. The temporary absence of young people in the local community rendered the dance life to be disorganised as they were not involved in the dance events, neither as organisers nor as participants. ${ }^{25}$ Based on my older informants' narratives, during the hopeless situation of famine caused by the dry weather, people did not find in their heart to dance and celebrate, all the attention has been turned to the problems of everyday living.

Besides the interruption of dance life, another adaption practice has to be mentioned as a response to the state of emergency triggered by an environmental catastrophe. A music band of three members (József Lukács - violin, Mihály Avadeni - lute and singing, György Csernik accordion $)^{26}$ has been formed in Magyarfalu and they travelled around the region to provide music services. The musicians visited wealthier families for whom they played not for money but for basic food commodities. They have been travelling on a carriage from Bucovina to Dobruja and in every 2 or 3 weeks, they returned back home. The players used to be the so called 'peasant musicians', that is, they did not play for compensation but for having fun or every now and then, for entertaining the others. In this period, the Gypsy musicians have been regarded as professionals who were hired to play music at the dance events or they went peddling by themselves. However, there is no data regarding the Gypsy musicians' services in the 1940s, I suppose that during the period of drought the Moldavian culture of music has been affected by ethnic and regional interactions due to the musicians travelling around for 1 or 2 years.

In light of the above, examples stand to outline the adaptation practices applied in the community of Magyarfalu in order to survive during the temporary crises, additionally, it is also demonstrated that how these factors relate in a direct or indirect way to the dance culture. Ordinarily, the behaviour of the three musicians would have been disgraceful as peddling was despised and the act of playing music for remuneration was contributed to the Gypsies. Even so, the practice appearing in the above described case was accepted as a survival strategy. The drought in 1946-1947 caused solely a temporary disorder in the regular way of living in Magyarfalu, however, the fact the dance culture has almost completely disappeared raises the following question: what degree of importance is attributed to dancing when the purpose of satisfying the

${ }^{24}$ In addition to that, further events affected the previously closed and cohesive community in a negative way, e.g. the Second World War (1939-1945); the local typhoid epidemics (1945); and the translocation of 40 families from Magyarfalu to Hungary (1941-1947) (Szónyi, 2015: 183).

25 In the 1940s, solely the youngsters, those who have not been married so far, were allowed to participate in those occasions. An exception has been made for the marriage proposals and the weddings when the married people and the elders had a permission to dance.

${ }^{26}$ Solely György Csernik is alive, he was 15 years old in 1947, and he claims he learned to play on his instrument mostly in this period, making music together with the two older musicians. 
basic needs of the individual or the community comes to the picture, additionally, what role can dancing play in the social structure?

\section{The function of dance culture in the community of Magyarfalu}

Dancing is a sociocultural practice and facilitates the obtaining of resources, thus contributes to the preservation of social continuity. I consider the gained resource as capital, the obtaining of which becomes possible for the member of the community if the traditional dance culture is operated collectively. Several researchers has already embarked on the way to define the capital in a sociological context and identify the types thereof (economic, social, cultural, and symbolic) (see Bourdieu, 1986; Coleman, 1990; Farkas, 2013), however, the present essay does not aim to give a critical summary on the diverse definitions and typologies that sometimes differ remarkably from each other. Starting from the general sociological definition, according to which 'capital is a sum of social resources possessed by a given individual or a group' (Farkas, 2013: 2), I am aimed at outlining briefly the basic functions fulfilled by the dance culture in Magyarfalu.

Through the introduction of adaptation practices applied by the community of Magyarfalu, it has been seen that by the way of dance culture, interpreted in a wider context, the members of the community might gain cultural capital, that is, knowledge, social capital as they extend their social relations, and earn economic capital by increasing their financial assets. Knowing and practising the traditional dances is a form of non-verbal communication which facilitates the expression of individual emotions and knowledge, in addition to that, enables to strengthen the local identity. This plays a role in the development of social relations and in the local socialization, moreover, by representing the system of rules and social relations in the community, functions to strengthen the norms. A dance event allows to gain experience and works as a 'safety valve' which interrupts the monotonous day-to-day reality, participates in the physical and mental refreshments of an individual, thereby mitigating the tension and cutting back the hidden conflicts in the community. In the context of dance culture, the service provided by the musicians is also included, providing livelihood for the Gypsy musicians' group, in which a specific knowledge is required.

The termination of local dance life during the period of drought, which phenomenon was presented earlier, might be explained by the fact that the community's social network was exposed to fast transformation due to the labour migration of the young population while the local dance tradition was not able to adopt to the new situation. Furthermore, considering that a significant amount of effort has to be devoted to dancing and organizing the dance occasions, it was not advisable to consume such a great amount of energy when the famine occurred.

Certain parts of the dance culture might derive from satisfying several basic human needs. As a social institution, it contributes in a direct or indirect way to give a collective reaction to the following needs: nutrition (the food supply is ensured by gaining economical assets), reproduction (deepening the social relations, it becomes easier to enter into marriage), safety (as a symbolic way of representation, the dance culture might reinforces the protection provided by the community), health (the body exercise hardens the physical resistance and regenerates the mental health), movement (the dance culture opens a communicative space, thus facilitating the flow of information), growth (a specific knowledge can be gained).

To sum up, the present research regards the dance as a tool for raising capital, takes dancing as a sociocultural practice, and determines the dance culture to be the system of social institutions which contributes to the harmonious functioning of social life, through which, plays a role in sustaining the social continuity. 


\section{Conclusions}

The present study commenced with the aim of examining the dance culture of a Moldavian Csángó village, namely Magyarfalu, by applying a holistic approach, focusing on the changes, and highlighting the triggers thereof, that is, the adaptation practices, in addition to that, the presentation of those ecologic, economic, social, and cultural mechanisms that lie behind these phenomena is also in the scope of the research.

Applying the combination of the two theoretical frameworks of the biopsychological and the structural-functionalist approach in dance anthropological research is only possible when the visible and hidden dimensions of the dance culture remain in their context, the concept of cultural complexity is kept in mind, and the observation turns towards the cultural elements from a holistic point of view. The applicability of the action-based functionalist discipline becomes relevant when it comes to the micro level observation of the dance and the dancing community, while the approach of structural-functionalism turns to account as long as the local dance culture is examined in a wider, macro level context. The function fulfilled by certain parts of the dance culture and their role played in the social structure can be determined when the dance itself is regarded not only as a movement system but as sociocultural practice.

The examples of Magyarfalu indicate that individual and social adaptation practices lie behind the transformation of dance life and the changes happening to the dances. The appearances of the csárdás in the village's dance repertoire might be interpreted as a cultural adaptation practice which lead us back to the 'Csángó-saving' movement and the presence of rural tourism. The institutional aspect of social adaptation is demonstrated by the vanishing of the konónia dance event which has been prohibited among the youngsters by the local parish priest grounding his order on moral aspects. The adaptation to the natural environment is shown by the temporary termination of dance life and the forming of an impermanent travelling music band which phenomena results from the drought and famine occurred in 1946-1947.

The adaptation practices are not regarded solely as a reaction or the results of micro and macro level changes. During the adaptive process, a given community activates more segments simultaneously of its sociocultural system, additionally, finds creative solutions to satisfy its needs and sustain the social balance. In my opinion, the adaptation is more than being aligned to the circumstances (for the purpose of survival), this is a creative process which updates the knowledge gathered about the world and extends the set of cultural elements with a varying amplitude. This way, the adaptation ensures the members of the given community that the social milieu in which they live preserve its following features: viable, ensuring safety and certainty; culturally rich, thus remaining valuable and honoured. All members of the local community participate in this creative process, and due to the fact that each micro community consists of distinct individuals, the cultural diversity becomes sensible through these adaptation practices when the cultures are lined up.

This research has not been concluded yet and shall continue with its explicit aim to observe the folk dance culture in its social reality by leaving behind the romantic and idealistic aspects, stepping out from the national and ideological discourses, and applying a relativist and reflexive approach. I hope that the theoretical framework of this article inspires and initiates further researches in the field of dance anthropology and the outcomes shall be relevant for several disciplines of human, social, and historical studies.

\section{Acknowledgement}

The research was supported by project no. K 142270, which was financed by the Hungarian National Research, Development, and Innovation Office. Grateful thanks to Tímea Mészáros for translation of the paper. 
Conflicts of interest: none.

\author{
References
}

A. Gergely, A. (2010a). Funkcionalizmus [Functionalism]. In: A. A. Gergely, R. Papp, A. Szász, G. Hajdú \& A. Varga (Eds.), Antropológiai - etnológiai - kultúratudományi kislexikon (p. 162). Budapest: MTA PTI Etnoregionális és Antropológiai Kutatóközpont. Retrieved 4 June 2018, from http://www.mtapti.hu/pdf/No 108 Antropolexikon.pdf.

A. Gergely, A. (2010b). Holizmus, holisztikus szemlélet [Holism, holistic approach]. In: A. A. Gergely, R. Papp, A. Szász, G. Hajdú \& A. Varga (Eds.), Antropológiai - etnológiai - kultúratudományi kislexikon (pp. 174-175). Budapest: MTA PTI Etnoregionális és Antropológiai Kutatóközpont. Retrieved 4 June 2018, from http://www.mtapti.hu/pdf/No_108 Antropolexikon.pdf.

Boglár, L., \& A. Gergely, A. (2010). Funkcióelmélet [The theory of function]. In: A. A. Gergely, R. Papp, A. Szász, G. Hajdú \& A. Varga (Eds.), Antropológiai - etnológiai - kultúratudományi kislexikon (p. 161). Budapest: MTA PTI Etnoregionális és Antropológiai Kutatóközpont. Retrieved 4 June 2018, from http://www.mtapti.hu/pdf/No 108 Antropolexikon.pdf.

Bourdieu, P. (1986). The forms of capital. In: J. G. Richardson (Ed.), Handbook of theory and research for the sociology of education (pp. 241-258). New York: Greenwood Press.

Coleman, J. S. (1990). Foundations of social theory. Cambridge: The Belknap Press of Harvard University Press.

Csüry, B. (1930). Néprajzi jegyzetek a moldvai magyarokról [Ethnographic notes about Hungarians of Moldavia]. Kolozsvár: Minerva.

Eriksen, T. H. (2006). Kis helyek - nagy témák: Bevezetés a szociálantropológiába [Small places, large issues: An introduction to social anthropology]. Budapest: Gondolat Kiadó.

Eriksen, T. H. (2008). A társadalmi és a kulturális integráció komplexitása [The complexity of social and cultural integration]. Regio, 19(4), 3-23.

Farkas, Z. (2013). A társadalmi tőke fogalma és típusai [The definition and types of social capital]. Szellem és Tudomány, 4(2), 106-133.

Felföldi, L. (1996). A funkció vizsgálata a magyar néptánckutatásban [The analysis of function in Hungarian ethnochoreology]. Tánctudományi Tanulmányok (pp. 100-108), Budapest: Magyar Tánctudományi Társaság.

Fügedi, J. (2018a). Notating dances from films: A method in Hungarian ethnochoreology. Journal of Movement Arts Literacy, 4(1), Article 5. Retrieved 13 July 2018, from http://digitalcommons.lmu.edu/cgi/viewcontent.cgi?article=1026\&context=jmal.

Fügedi, J. (2018b). Egyidejű mozdulatesemények, párhuzamos témák, térbeli ellentétek: a néptánc összehasonlító tartalmi elemzése [Synchronous movement events, parallel themes, spatial oppositions: A comparative content analysis of traditional dance]. Ethnographia, 129(1), 69101.

Giurchescu, A., \& Torp, L. (1991). Theory and methods in dance research. A European approach to the holistic study of dance. Yearbook for traditional music 23 (pp. 1-10). International Council for Traditional Music.

Hatos, P. (2002). Szempontok a csángókutatás kulturális kontextusainak értelmezéséhez [Viewpoints for the interpretation of cultural contexts of Csángó research]. Pro Minoritate, 22(4), 5-16.

Hollós, M. (1995). Bevezetés a kulturális antropológiába [An introduction to cultural anthropology]. Budapest: ELTE BTK Kulturális Antropológiai Szakcsoport. 
Iancu, L. (2013). Vallás Magyarfaluban [The religion in Magyarfalu]. Pécs: L'Harmattan - PTE NéprajzKulturális Antropológia Tanszék.

Ilyés, S., Peti, L., \& Pozsony, F. (Eds.) (2010). Moldvai csángók 1990-2010. A Kriza János Néprajzi Társaság Értesítóje [Moldavian Csángós 1990-2010. Bulletin of Kriza János Ethnographic Society]. 16(1-2), Kolozsvár: Kriza János Néprajzi Társaság.

Ilyés, S., Pozsony, F., \& Tánczos, V. (Eds.). (2006). A moldvai csángók bibliográfiája [The bibliography of Moldavian Csángós]. Retrieved 29 June 2018, from http://csangobibliografia.adatbank.transindex.ro/bibl.php?a=bibl.

Kaeppler, A. (1991). American approaches to the study of dance. Yearbook for traditional music. 23 (pp. 1121). International Council for Traditional Music.

Kavecsánszki, M. (2014). Tánc és politika. Szempontok a tánckultúra és a politikai akaratképzés közötti kapcsolat értelmezéséhez [Dance and politics. Viewpoints for the interpretation of relation between dance culture and political power]. Híd. 3, 74-89.

Kavecsánszki, M. (2015). Tánc és közösség: A társastáncok és a paraszti tánckultúra kapcsolatának elmélete bihari kutatások alapján [Dance and community. The theory of relation between ballroom dances and peasant dance culture on the basis of researches in Bihar]. Debrecen: Debreceni Egyetemi Kiadó.

Kinda, I. (2010). Ellenörzött közösségek. Szabályok, vétkek és büntetések a moldvai csángó falvakban [The controlled communities. Rules, vices, and punishments in Moldavian Csángó villages]. Marosvásárhely: Mentor Kiadó.

Kisdi, B. (2012). A kulturális antropológia története, elméletei és módszerei [The history, theories and methods of cultural anthropology]. Budapest: Pázmány Péter Katolikus Egyetem.

Kürti, L. (1995). Antropológiai gondolatok a táncról [Anthropological thoughts about the dance]. In: E. Zakariás (Ed.), Kriza János Néprajzi Társaság Évkönyve 3 (pp. 137-153), Kolozsvár: Kriza János Néprajzi Társaság.

Martin, Gy. (1996). Magyar tánctípusok és táncdialektusok [The Hungarian dance types and dance dialects]. Budapest: Planétás Kiadó.

Molnár, P. (2011). „...a néptáncot átalakították...” Hagyomány és modernizáció egy erdélyi falu tánckultúrájában [,...the folk dance has been transformed...” Tradition and modernization in dance culture of a Transylvanian village]. Belvedere meridionale, 23(1), 48-76.

Pál-Kovács, D. (2014). A női szemlélet helye a néptánckutatásban [The place of female perspective in ethnochoreology]. In: G. Bolvári-Takács, J. Fügedi, K. Mizerák \& A. Németh (Eds.), Alkotás befogadás - kritika a táncmüvészetben, a táncpedagógiában és a tánckutatásban (pp. 84-89). Budapest: Magyar Táncmúvészeti Főiskola.

Peti, L. (2006). A csángómentés szerkezete és hatásai az identitásépítési stratégiákra. [The structure and effects of Csángó's salvage on strategies of identity building.]. In: A. Zs. Jakab \& Á. T. Szabó, (Eds.), Lenyomatok 5. Fiatal kutatók a népi kultúráról. Kriza Könyvek 27 (pp. 129-155). Kolozsvár: Kriza János Néprajzi Társaság.

Pozsony, F. (2005). A moldvai csángó magyarok [The Csángó Hungarians of Moldavia]. Budapest: Gondolat Kiadó-Európai Folklór Intézet.

Radcliffe-Brown, A. R. (2004). Struktúra és funkció a primitív társadalomban [Structure and function in primitive society.]. G. Biczó (Ed.). Debrecen: Csokonai Kiadó.

Sándor, I. (2006). „Zene és tánc úgy, mint Széken” A táncház, mint folklorizmus- és művelődési jelenség [Music and dance like in Szék. The dance house as folklore and cultural phenomenon]. In: I. Sándor (Ed.), A betonon is kinő a fü. Tanulmányok a táncházmozgalomról (pp. 23-39). Budapest: Hagyományok Háza.

Székely, A. (2017). Erdélyi táncos-zenész adatközlők „testközelből” [Transylvanian dancer and music player informants at close quarters]. In: N. Glässer \& G. Takács, DiákKörKép 3: Tudományos 
diákköri írások a néprajz szegedi múhelyéből (pp. 51-73). Szeged: SZTE Néprajzi és Kulturális Antropológiai Tanszék.

Szőnyi, V. (2014a). A magyarországi táncházmozgalom hatása egy moldvai csángó település tánckultúrájára [The effect of Hungarian dance house movement on dance culture of a Moldavian Csángó settlement]. In: Z. Vajda (Ed.), Tehetségek a tudomány horizontján. Válogatás a Szegedi Tudományegyetem Bölcsészettudományi Kara hallgatóinak tudományos munkáiból (pp. 295309). Szeged: Szegedi Tudományegyetem Bölcsészettudományi Kar.

Szőnyi, V. (2014b). A moldvai csángó magyar táncok funkcionális és formai-stiláris változásai [The functional and formal-stylistic changes of Moldavian Csángó dances]. In: G. Bolvári-Takács (Ed.), ALKOTÁS - BEFOGADÁS - KRITIKA a táncmüvészetben, a táncpedagógiában és a tánckutatásban (pp. 180-188). Budapest: Magyar Táncmüvészeti Főiskola.

Szőnyi, V. (2015). A moldvai csángó magyarság [The Csángó Hungarians of Moldavia]. In: B. Gatti (Ed.), Idegen fódre siettem...: Moldvai csángók Baranyában (pp. 187-197). Budapest: Nap Kiadó.

Szőnyi, V. (2016). Hatalom és erkölcs a moldvai csángó tánckultúrában [Authority and morality in the Moldavian Csángó dance culture]. In: G. Bolvári-Takács (Ed.), Tánc és Társadalom (pp. 190196). Budapest: Magyar Táncmúvészeti Főiskola.

Tánczos, V. (2003). Csángó reneszánsz? [Csángó renaissance?]. Korunk, 14(9), 61-73.

Varga, S. (2017). Use of Space in the Dance-House in the Mezőség Region. In: K. Steppuat (Ed.), Dance, senses, urban contexts (pp. 104-112). Herzogenrath: Shaker Verlag.

Veress, S. (1989). Moldvai gyújtés. [The Moldavian fieldwork.]. Berlász, M. \& Szalay, O. (Eds.), Budapest: Múzsák Kiadó. 